\title{
Community Capacity in The Face Of Landslide Hazards in the Southern Of Semarang City
}

\author{
Heri Tjahjono ${ }^{1, *}$, Suripin $^{2}$, and Kismartini ${ }^{1}$ \\ ${ }^{1}$ Doctoral Program of Environmental Science, School of Postgraduate Studies, Diponegoro University, Semarang-Indonesia
}

\begin{abstract}
The study was done at Semarang, Central Java. The aims of the study are: (a) to know the variation in the level of community capacity in dealing with landslide hazards in the southern of Semarang city; (B) to know the factors that affect the capacity of communities in facing the hazards of landslides. This research was conducted by the sample method with a sample of 198 people, taken by purposive sampling. Samples taken are people living in areas that have experienced landslide or in areas that are expected to be vulnerable to landslides. The variables used in this research are (1) regulatory and institutional capacity in the prevention of landslide disaster, (2) early warning system in community, (3) education of disaster skill training, (4) mitigation to reduce basic risk factor, and (5) Preparedness on all fronts. Data were collected with questioner and interviews. Data analys is was performed by percentage descriptions, and map overlay analysis using ArcGIS release 10.3 technology. The result of the research shows that there are 5 variations of society's capacity level in facing the landslide hazard in southern Semarang city, that is the very high capacity of society as much as $4,35 \%$ of the people that researched, the high community capacity is $7,25 \%$ of the people that researched, the medium community capacity is $30.43 \%$. of the people that researched, low community capacity as much as $36.23 \%$ of the people that researched and very low community capacity as much as $21.74 \%$ of the people that researched. Based on the result of overlay map of landslide threat in southern Semarang City with map about variation of community capacity level in facing landslide hazard indicate that community capacity with very high criterion and high occupancy area of threat of landslide with high and medium criterion which have been experienced landslide. While the capacity of the community with the criteria of medium, low and very low occupies the threat of landslide areas with high, medium, low and very low criteria that have never experienced landslide. The existence of the experience of a landslide disaster is one of the factors that encourage the community to increase the community capacity in facing the landslide.
\end{abstract}

\section{Introduction}

Based on the data of several types of natural disasters occurring in Indonesia, landslide are ranked third compared to other disasters seen from the number of fatalities form 2010 to 2014 . More than $15 \%$ or as many as 3.074 people died from landslide. These year to year incidents in Indonesia show a significant number. The presence of a relatively high landslide incident followed by great losses requires serious attention [1].

Central Java is one of the provinces in Indonesia that is vulnerable to natural disasters, such as earthquake, volcanic eruption, and landslide. The location is traversed by the path of young mountains resulting in its several places are still moving and prone to landslide. Moreover, the global climate changes has caused an increase in rainfall. However, the land quality due to deforestation is declining. These result in high landslide occurrences. Landslide incidents in Central Java from 2011-2015 has the highest frequency compared to other disasters, i.e. 568 incidents [1]. Primarily, for landslide, the data shows that the incidents in the city of Semarang has a high frequency. In 2012 itself, there are 39 incidents, 44 times in 2013, and 123 times in 2014[2]. There is a significant increase from 39 times of incidents in 2012 to 123 times in 2014. The escalation of landslides is always followed by increased loss of

Corresponding author: heriridlo@yahoo.com 
both casualties and properties. This is due to the lack of disaster risk management.

The example of a landslide incident in the city of Semarang was the one happened in Terangkil Sejahtera and Terangkil Baru Residencies on January 23rd, 2014. The disaster had destroyed 23 houses, meanwhile others are severely damaged and unlivable.

Semarang is one of the cities in Central Java that often experiences landslides. Geologically, areas in Semarang consist of some formations. They are Damar, Marine/Kalibiuk, Kaligetas/Notopuro, Central Ungaran, Jongkong, and Alluvium formations. Each of them composes of different types of rock and soil. The existing rocks varies from marine layers, damar formation sedimentary rock, white claystone, volcanic sedimentary breccia, volcanic sedimentary lava of Central Ungaran Mount, and volcanic rocks of Old Ungaran Mount. These variations may lead to various landslide disasters [3]

The impact of disaster varies. It depends on the condition of environmental vulnerability and the capacity of society. If the society is unprepared (having low capacity), disasters will cause panic, prolonged suffering or sadness, such as; injuries, deaths and economic pressure resulting from loss of jobs and property, loss of family members and damaged to infrastructure, also environment. This means, the society management towards disasters needs to be reorganized [4].

Human or society in the context of a disaster is the object as well as subject of the disaster itself. They not only deal with pre-disaster threat, but also take the risk of losing lives and belongings due to the disaster, and they still have to face the post-disaster condition; recovering themselves physically and mentally. Therefore, there needs to be an effort to improve the ability or capacity of the society in facing disaster [5]

The objectives of this research is (a) finding out varies level of society capacity in facing the danger of landslide, in southern Semarang city. (b) finding out factors influencing the society capacity in coping with landslide.

\section{The Concept of Landslide}

Landslide is a process of transfer of soil mass or rocks with a sloping direction from its original position, so that it is separated from a stable mass due to the influence of gravity; rotational and translational movements [6]. Landslide is one type of soil mass or rock motions, or a mixture of both, moving out or down falling the slope due to the disturbance of soil stability or the constituent rocks of the slope [7]. Landslide is a potential mechanism for mobilizing and spreading pollutant [8]. Landslide and rock falls may occur in the city, and the government pours a considerable spending on investigation, design and mitigation implementation, and preventive measures to reduce the liability of life loss and economic losses [9].

According to a guideline of the spatial planning on areas proning to landslide, the process triggering the occurrence of landslides is the infiltration of water into the soil and a very high level of the slopes. The present of water seeping into the soil will increase its weight due to high rainfall. If the water penetrates to the impermeable soil that acts as the slip-plane, it will become very slippery and the obsolete soil above it will move along the slopes. Fakhruddin [10] stated that landslide is a transfer of slopes forming materials in the form of rocks, or mixed material downfalling or out of the slope.

Suripin [11] defines, landslide is a form of erosion where the transportation or movement of the soil mass occurs at the same point in and in a relatively large volume. In terms of movement, there are some erosion caused by. They are creep, rock fall, and mud flow. The moving mass in the landslide is usually massive and resulting in fatalities; environmental, agricultural land, residencies, possession and infrastructural damages, not to mention loss of lives. According to Directorate of Geology and Environmental Governance, soil movement or landslide is a product of the balance disturbance process of the slope causing the soil mass and rocks to down move.

Based on the definitions above, thus, landslide in this study is defined as mass movement type which move/slide or rotate, and the flowing object are mixed/modified material, soil and rocks due to gravity, that differs with others in terms of movement and less water content.

\section{The Capacity of the Society}

Capacity is elaborated as a combination of all strengths existing in a community, society and organization that may reduce the impact of a risk or a disaster [12]. Some elements influencing the capacity are policy, readiness, and social participation. Increasing the capacity is aimed to develop a safety culture, where community members are aware of the present danger, knowing how to selfprotect, and supporting the effort to protect others and society in general.

Institutional strengthening, whether governmental, public, or even private is the key factor in the effort of disaster management. The community has an important role to prevent calamity. Disaster prevention is a series of activities undertaken to reduce the risk of disaster, through the reduction of threats or those vulnerable to disaster threat [13]. Capacity is a set of ability which enable the society to have higher endurance against threatening danger, and increasing both a defense as well as capability of the community to overcome the 
impact of harmful circumstance. This may relate to sources, skills, knowledge, organizational competence and attitude to act and response toward a crisis [14]

The risk of an occurred disaster relates to human capacity in dealing with it. Meaning, the action directing to a catastrophe management will be able to minimize the occurrence, so that the massive loss is avoidable. In relation to that, the social capacity in the area prone to disaster needs to be investigated for developing. The next is building the institutional capacity in response to dangerous occurrence to effectively overcome it [10].

There are many researches relevant to threats/dangers and landslide vulnerability. The prior studies mainly focuses on the factors causing landslides and the efforts to cope with landslides physically, socially, and policy $[15,16]$. However, only few researchers focus on the capacity of the communities in the management of landslide. Whereas, the community is the most disadvantaged party from the disaster. Hence, as a researcher, the writer would like to review more about the management of disaster risk reduction by increasing the capacity of the community as an effort to minimizing loss and casualties of landslides $[15,17]$.

Capacity is a set of ability which enable the society to have higher endurance against threatening/disastrous danger, and increasing both a defense as well as capability of the community to overcome the impact of harmful circumstance. This may relate to sources, skills, knowledge, organizational competence and attitude to act and response toward a crisis [14,18].

There are several kinds of capacity in dealing with disaster. (1) Physical capacity, ability to obtain materials/stuffs needed to rebuild infrastructures in the community; (2) Social Economic capacity, when the demand for various goods is available, the need for organized special skillful human resources also emerges, in order to rebuild their community; (3) Organizational/institutional capacity, the presence of family and community based institution with its leader and systemized decision making; (4) Economic capacity, the presence of ability in business sector to repair and restore the community economy; (5) Motivational capacity, positive and strong motivational people, with determination to survive, love, and care for others, courage and willingness to help each other.

Vulnerability and calamity threats make it an absolute capacity to develop. The bigger the capacity and community ability to manage disaster, the smaller impact on loss and casualties will be. This is what is pioneered in disaster risk reduction.

\section{Methods}

This research is conducted in the southern of Semarang city, the Province of Central Java. Considering the frequent occurrence of landslides in Semarang causing loss, both belongings and human lives. The research on 'social capacity in dealing with landslide' is an observational one, using quantitative descriptive analysis. It makes a description about on-field condition with systematical, factual, and accurate illustration of the facts, characteristics, and reviews the correlation between investigated phenomena [15].

The population of this research is the field physical condition and the residences/people living in a developed area in Semarang. The sample is taken to field unit and conducted purposively, based on certain considerations and objectives. The consideration stated is that people living in areas having experienced landslides or are prone to landslide. The sample community is 196 . While the physical field to sample a total of 69 terrain units.

Material used covers soil and rocks, which will be analyzed in soil laboratory. The devices used in this research are GPS, Geology Compass, Clinometer, Abney level, Indonesia Earth Map, satellite imagery, foothills Map, Geology Map, Population Distribution and Density Map, Soil Map, Plastics for sample, Soil Knife, Analysis Scale, A set of soil texture test device, and a set of soil consistency test device.

The researched variables are (1) Variable of Threat, threat is a potential disaster in area scale, time and inhabitants, this includes some indicators: (a) Geomorphology (declivity of slopes), (b) soil texture, (c) rocks type (geology), (d) history of landslide occurance, (e) structure of rocks layering, (f) Water plan of foothills/seepages, (g) Vegetation density, (h) excavating/cutting off slopes, (i) rainfalls; (2) Variable of Social Capacity. Scoring for Social capacity indicator by using Framework for Actions Hyogo basically consists of five components, (a) regulation and institution of disaster management, (b) early warning and disaster risk assessment, (c) disaster education, (d) basic risk factor lessening, and (e) all-lines readiness development.

The first data taken from the field is on landslide threats. This covers (a) Geomorphology (declivity of slopes), (b) soil texture, (c) rocks type (geology), (d) history of landslide occurrence, (e) structure of rocks layering, (f) Water plan of foothills/seepages, (g) Vegetation density, (h) excavating/cutting off slopes, (i) rainfalls. The second data is about the Social capacity in coping with landslide disaster. It covers (a) regulation and institution of disaster management, (b) early warning and disaster risk assessment, (c) disaster education, (d) reduction of basic risk factor, and (e) alllines alertness development. The later data is obtained by doing questionnaires and interviews with the sample residents. It is then analysed using enhancement scoring, AHP analysis, and overlay analysis assisted by ArcGIS technology. 


\section{Result and Discussion}

\subsection{Description of Researched Area}

This research is conducted in the city of Semarang which is the capital of Central Java. Geographycally, it is positioned in between $109^{0} 35^{\prime}-110^{\circ} 50$ ' East Longitude and $6^{0} 50^{\prime}-7^{0} 10^{\prime}$ South Latitud and occupying an area of 38.449,94 Ha. Semarang consists of 16 districts with administered borders as follows: in the North with Java Sea, in the South with Semarang regency, in the East with Demak and Grobogan Regencies, and in the West with Kendal Regency.

The researched area has a quite high rainfall. The maximum rainfall is $2265 \mathrm{~mm} /$ year, can be seen in Kandri Station, and the minimum is $1483 \mathrm{~mm} /$ year can be seen in Candi Rain station. According to Schmidt Ferguson the researched area has the same type of climate, type C (slightly wet), grade Q (comparison between the average of dry months and wet months) which is slightly different.

Geological condition, both structural and rock formation will affect to the existence of the main rock and soil development., so that the soil physical and geotechnical characteristics are unable to separate from the main rock character. The researched area consists of some rock formations. (1) Alluvium sedimentary, (2) Kaligetas formation, in Van Bemmelen (1941) is called Notopuro formation, (3) Damar formation, (4) Kalibeng formation (5) Kerek formation, by Van Bemmelen (1941) Kalibeng dan Kerek formations are called Kalibiuk/Marine formations, (6) volcanic sedimentary lava of Central Ungaran Mount, and (7) Jongkong formation or volcanic rocks of Old Ungaran Mount.

\subsection{Result of the Study}

\subsubsection{Social Capacity in Generally Coping with Landslide Disaster}

Based on tabulation result and research data analysis, the social capacity in generally coping with landslide disaster is describes in Table 1.

Table 1. Social Capacity in Coping with Landslide

\begin{tabular}{ccccc}
\hline No & Value Interval & Crite ria & Frequency & Percentage (\%) \\
\hline 1 & $1-<1.8$ & Very Low & 15 & 21.74 \\
2 & $1.8-<2.6$ & Low & 25 & 36.23 \\
3 & $2.6-<3.4$ & Medium & 21 & 30.43 \\
4 & $3.4-<4.2$ & High & 5 & 7.25 \\
5 & $4.2-5$ & Very High & 3 & 4.35 \\
& & Total & 69 & 100 \\
\hline
\end{tabular}

Table 1. explains that the social capacity in generally dealing with landslide is $21.74 \%$ of the investigated respondence belongs to very low criteria, $36.23 \%$ belongs to social capacity with low criteria, and the medium criteria is $30.43 \%$. Next is $7,25 \%$ for those belong to high criteria, and $4,35 \%$ for Social capacity with very high criteria.
In detail, the social capacity for each sub-variable is described as follows.

\section{A. Regulation and institution of disaster management}

Table 2. The Social Capacity in Regulation and Institution

\begin{tabular}{ccccc}
\hline No & Value Interval & Criteria & Frequency & Percentage (\%) \\
\hline 1 & $0.2-<0.36$ & Very Low & 10 & 14.49 \\
2 & $0.36-<0.52$ & Low & 13 & 18.84 \\
3 & $0.52-<0.68$ & Medium & 28 & 40.58 \\
4 & $0.68-<0.84$ & High & 13 & 18.84 \\
5 & $0.84-1.00$ & Very High & 5 & 7.25 \\
& & Total & 69 & 100 \\
\hline
\end{tabular}

Table 2. shows that the social capacity in regulation and institution in dealing with landslide is $14,49 \%$ of the investigated respondence belongs to very low criteria, $40.58 \%$ belongs to medium criteria, $18.84 \%$ is high criteria, and $7.25 \%$ of the respondence includes in very high criteria rest in lower case. 


\section{B. Early Warning System}

Table 3. The Social Capacity in Early Warning System

\begin{tabular}{ccccc}
\hline No & Value Interval & Criteria & Frequency & Percentage (\%) \\
\hline 1 & $0.2-<0.36$ & Very Low & 35 & 50.72 \\
2 & $0.36-<0.52$ & Low & 26 & 37.68 \\
3 & $0.52-<0.68$ & Medium & 8 & 11.59 \\
4 & $0.68-<0.84$ & High & 0 & 0 \\
5 & $0.84-1.00$ & Very High & 0 & 0 \\
& & Total & 69 & 100 \\
\hline
\end{tabular}

Table 3 explains that $50,72 \%$ of the investigated respondence of the social capacity on early warning in coping with landslide belong to very low criteria,
$37.68 \%$ included in low criteria, $11.59 \%$ of the respondence belong to medium, while for high and very high criteria the percentages are not found.

\section{Education and Training in Disaster}

Table 4. The Social Capacity in Disaster

\begin{tabular}{ccccc}
\hline No & Value Interval & Criteria & Frequency & Percentage (\%) \\
\hline 1 & $0.2-<0.36$ & Very Low & 18 & 26.09 \\
2 & $0.36-<0.52$ & Low & 28 & 40.58 \\
3 & $0.52-<0.68$ & Medium & 13 & 18.84 \\
4 & $0.68-<0.84$ & High & 9 & 13.04 \\
5 & $0.84-1.00$ & Very High & 1 & 1.45 \\
& & Total & 69 & 100 \\
\hline
\end{tabular}

Table 4 shows that the social capacity on disaster education in facing landslide is $26,09 \%$ of the investigated respondence belong to very low criteria,
$40.58 \%$ is included in low criteria, $18.84 \%$ belong to medium, $13.04 \%$ is high criteria, and $1.45 \%$ of them belong to very high.

\section{Reduction of Basic Risk Factors}

Table 5. The Social Capacity in the Reduction of Basic Risk Factors in Disaster

\begin{tabular}{ccccc}
\hline No & Value Interval & Criteria & Frequency & Percentage (\%) \\
\hline 1 & $0.2-<0.36$ & Very Low & 9 & 13.04 \\
2 & $0.36-<0.52$ & Low & 21 & 30.43 \\
3 & $0.52-<0.68$ & Medium & 20 & 28.99 \\
4 & $0.68-<0.84$ & High & 14 & 20.29 \\
5 & $0.84-1.00$ & Very High & 5 & 7.25 \\
& & Total & 69 & 100 \\
\hline
\end{tabular}

Table 5 explains that $13,04 \%$ of the investigated respondence in this criteria belong to very low, 30.43
$\%$ belong to low, $28.99 \%$ is medium criteria, $20.29 \%$ is included in high, and $7.25 \%$ is very high. 


\section{E. All-Lines Alertness Planning.}

Table 6. The Social Capacity in All-lines Alertness Development

\begin{tabular}{ccccc}
\hline No & Value Interval & Criteria & Frequency & Percentage (\%) \\
\hline 1 & $0.2-<0.36$ & Very Low & 13 & 18.84 \\
2 & $0.36-<0.52$ & Low & 28 & 40.58 \\
3 & $0.52-<0.68$ & Medium & 12 & 17.39 \\
4 & $0.68-<0.84$ & High & 9 & 13.04 \\
5 & $0.84-1.00$ & Very High & 7 & 10.14 \\
& & Total & 69 & 100 \\
\hline
\end{tabular}

Based on Table 6 above, it is shown that $18.84 \%$ of the investigated respondence belongs to very low criteria, $40.58 \%$ of them belong to low, $17.39 \%$ is medium, 13.04 $\%$ is included in high, and $10.14 \%$ of the respondence belong to very high criteria.

\subsubsection{Factors Influencing The Social Capacity in Facing the Danger of Landslide}

The result of this study shows that, there are some factors influencing the high-low or strength-weakness of the community capacity in dealing with landslide disaster, such as; (a) regulation and institution of disaster management, (b) early warning system, (c) education, training and skills on landslide disaster, (d) mitigation to reduce basic risk factors, (e) all-lines alertness planning, (f) experience in disaster, (g) concern attitude, (h) economy capacity, i.e. the presence of economy-business ability to repair and restore the community economy, (i) information network, affluence of access and management for useful information will increase the community capacity in facing disaster, (j) building organizational cooperation network.

\subsubsection{Discussion}

This study on the community capacity in coping with landslide risk shows a result dominated by very low criteria, low, up to medium. Owning the very low, low, to medium criteria are generally the areas with the same characters of landslide threat, i.e. very low, low, and medium. While the community capacity with high criteria, generally occurs in areas with the characters of medium, high, and very high landslide threat. For those belong to high and very high criteria, generally exist in areas that had experienced landslide before.

The community capacity relating with regulation and institution for managing landslide disaster, is further explained that most of the community have not noticed about regulations or local government law which regulate about disaster in the city of Semarang. This is due to the lack of regulation socialization to the community. Based on the interview with BPBD, the government has socialized the regulation, starting from district level to the head of village (Lurah). However, this does not continue to the level of Neibourhood/Community associations (RT/RW), causing part of the community not to know about disaster law or regulation.

Community capacity which relates to early warning system has very low and low criteria. The result of this study shows that most areas do not have early warning system toward landslide disaster, nor the information shared about it. Moreover, there have not been cooperation between the community with other institution about landslide disaster early warning, nor any evacuation paths relating to a disaster in the vicinity areas.

Social capacity in education, training and skills on landslide disaster, has very low, low, and medium criteria. The study shows that in most area, the community has not received training on landslide risk management, disaster simulation events in the vicinity of residential area. Moreover, there are still lacking of facility provided by the community or government to facilitate them accessing information about landslide disaster.

Community capacity in mitigation to reduce basic risk factors, on most areas is still dominated by very low, low, and medium criteria. The result of this research shows that in most of the areas, there are absence of, (a) social affair, in its effort to decrease the threats and the residents vulnerability toward landslide, (b) requirements to fulfill, in constructing buildings related to landslide risk, (c) information, stated that the particular area is a prone to landslide, (d) special groundwork, done by the community to face landslide threat that is likely to happen in the future.

Community capacity of all-lines alertness in most areas is still dominated by very low, low, and medium capacity. Result of study shows that in most areas, there are absence of (a) mechanism of emergency management disaster to lower the risk, (b) policy regulating emergency management disaster and its risk-decline, (c) appointed location as a shelter in case a landslide happens, (d) fund availability that is specially allocated for managing disaster in sub-district level, (e) logistic assistant availability in its effort to effectively control the crisis during landslide, (f) special officer in the level of 
Neighborhood Organization (RT) who is responsible for decision maker when landslide occurs, (g) special mechanism in the process of post-disaster recovery.

Experience about disaster may support to induce the community capacity. A person who had experienced a disaster, survived from it, even only had seen will indirectly motivate him/herself to survive another disaster. This is called inducing self-capacity to reduce disaster risk when happens.

Concern/caring attitude may support the increase of community capacity in coping with landslide disaster. A person's self-concern to survive from disaster and care for helping other will strengthen human capacity to deal with disaster. Caring attitude towards others may invite the community in a landslide mitigation.

\section{Conclusion and Recommendation}

The research and discussion conclude that: (1) There are 5 various levels of the community capacity in dealing with landslide disaster; very low, low, medium, high, and very high. On most areas the criteria are dominated by very low, low, up to medium. Owning the very low, low, to medium criteria are generally the areas with the same characters of landslide threat, i.e. very low, low, and medium. While the community capacity with high criteria, generally occurs in areas with the characters of medium, high, and very high landslide threat. For those belong to high and very high criteria, generally exist in areas that had experienced landslide before. (2) Factors influencing the ups and down or strength and weakness of community capacity in dealing with landslide, are; (a) regulation and institution of disaster management, (b) early warning system, (c) education, training and skills on landslide disaster, (d) mitigation for reducing basic risk factors, (e) all-lines alertness planning, (f) experience in disaster, (g) concern attitude, (h) economy capacity, i.e. the presence of economy-business ability to repair and restore the community economy, (i) information network, affluence of access and management for useful information will increase the community capacity in facing disaster, (j) building organizational cooperation network. Based on the results of this research, it is recommended that the government (BPBD), along with civil state apparatus, stuffs of villages, community leaders, and the society must be cooperating, assisting each others in landslide risk management, and trying to increase the community capacity in order to reduce or minimize disaster risk due to landslides.

\section{References}

1. BNPB, Panduan Perencanaan Kontijensi Menghadapi Bencana. Edisi II Jakarta, (2015).
2. BPBD. Data Bencana Tahunan di Kota Semarang, Badan Penanggulangan Bencana Daerah Kota Semarang, (2014).

3. Thanden, Sutisna, Peta Geologi Lembar SemarangMagelang, Direktorat Jendral Geologi Dan Sumber Daya Mineral, Bandung, (1996).

4. Hidayati, I. Y., \& Setyono, J. S, Jurnal Teknik PWK, 4(4), 591-603, (2005).

5. Lassa, J., Pujiono, P., Pristiyanto, D., Paripurno, E. T., Magatani, A., \& Purwati, H. Pengelolaan Risiko Bencana Berbasis Komunitas (PRBBK). Jakarta: PT. Gramedia Widiasarana Indonesia.

6. Peraturan Menteri Pekerjaan Umum No. 22/PRT/M/2007, Pedoman Penataan Ruang Kawasan Rawan Bencana Longsor, Departemen Pekerjaan Umum, (2007).

7. Imanda, Amy. Jurnal perencanaan Wilayah dan Kota vol 24 no 2. TML Energy, (2013).

8. Göransson, G., Norrman, J., Larson, M., Alén, C., \& Rosén, L, Journal Science of the Total Environment, 472, 481-495, (2014).

9. Kwong, A. K. L., Wang, M., Lee, C. F., \& Law, K. T, Journal Engineering Geology, 76(1), 27-39, (2004).

10. Fakhruddin, S. H. M., \& Chivakidakarn, Y, International Journal of Disaster Risk Reduction, 9,159-180, (2014).

11. Suripin, Pelestarian Sumberdaya Tanah dan Air. Andi, Yogyakarta, (2002).

12. UN-ISDR (United Nation secretariat of the International Strategy for Disaster Reduction), Living with risk : A global review of disaster reduction initiatives, Geneva: UN Publications, (2004).

13. Undang-undang Republik Indonesia Nomor 24 tahun 2007 tentang Penanggulangan Bencana, (2007).

14. Andersson-Sköld, Y., Bergman, R., Johansson, M., Persson, E., \& Nyberg, L, International Journal of Disaster Risk Reduction, 3, 44-61, (2013).

15. Karnawati, Dwikorita, "Geology for Regional Development," Modul Pelatihan Jabatan Fungsional Perencana Madya, Teknik Geologi Universitas Gajah Mada, Yogyakarta, (2005).

16. Yilmaz, I, Journal Geosciences, 35(6), 1125-1138, (2009).

17. Paripurno, Eko Teguh, Penanggulangan Bencana oleh Komunita, Yogyakarta: Pusat Studi Manajemen Bencana UPN Veteran Yogyakarta, (2006).

18. Paripurno, E.T. Manajemen Berbasis Komunitas : Seperti apa?. Bahan Diskusi pada Lokalatih Bencana Kulonprogo. Kulonprogo, 30-31 Januari 2001, (2001).

19. Nazir, M, Research Metod, Ghalia Indonesia. Jakarta, (2011). 